\title{
Analysis on the Types of Benefits of Gardens in Urban Areas: Comparison of Korea and Overseas Cases
}

\author{
Jiwon Park ${ }^{1}$ and Miae Jeong ${ }^{2 *}$ \\ ${ }^{1}$ Master's degree researcher, Garden research center, Korea National Arboretum, Pocheon-si, Gyeonggi-do, 11186, Korea \\ ${ }^{2}$ Researcher, Garden research center, Korea National Arboretum, Pocheon-si, Gyeonggi-do, 11186, Korea
}

\section{ABSTRACT}

Background and objective: Recently, there has been an increasing need for relaxation and familiarity with nature in residential and living spaces faced daily by urban residents, leading to a growing social interest in urban gardens. The aim of this study was to determine how gardens in a city provide physical and social benefits, comparing cases in Korea and overseas. Methods: We used the keywords "garden" and "city" for Korea, and "urban," "garden," and "green" for overseas. We then determined the Korean and overseas research trends in urban gardens by analyzing 63 Korean and 90 overseas articles deemed suitable for this study.

Results: As to the types of urban gardens, the most significant type was community gardens, both in Korea and overseas (30.2\% and $48.6 \%$, respectively), followed by rooftop gardens in Korea (22.2\%) and kitchen gardens overseas (22.2\%). Due to the narrow and complex urban structure in Korea, people focus on using rooftop, wall, and alley spaces, and tend to arrange container-type flexible gardens. Overseas there has been a focus on promoting health and reducing food inequality through allotment and kitchen gardens, and a tendency to use a larger area as a fixed form than Korea. In addition, it was found that gardens in urban areas had a positive effect on urban biodiversity.

Conclusion: To sum up, gardens in Korea are close to living spaces, and gardens overseas influence the ecosystem with an emphasis on food production. Therefore, creating urban gardens is a method of urban regeneration with a high utility that goes beyond mere food production, both in Korea and overseas, providing comprehensive benefits for the environment $(37.73 \%)$ and society (62.27\%). As such, continuous research on this area of study is needed to create policy guidelines for Korea.

Keywords: green space, physical and social environment, welfare

\section{Introduction}

The world's urbanization rate (ratio of the population living in urban areas) in 2018 is $55.3 \%$, due to industrialization and urbanization. This indicates that more than half of the world's population lives in cities. The urbanization rate in Korea is also approximately $81.3 \%$, as most of the population is concentrated in urban areas (World urbanization prospects, 2018). Urbanization causes traffic con- gestion and increased noise, deteriorating the living environment of urban residents. Moreover, nuclearization of families and increased anonymity are also reducing the community spirit (Lee et al., 2017). Beyond this, at the core of the overpopulated cities, there are problems such as destroyed habitats, decreased biodiversity, and reduced resilience of the ecosystem. These are only becoming more severe each day. The difficulty in securing green space also reduces quality of life for urban residents and damages the

This work was carried out with the support of Korea National Arboretum, Republic of Korea (Project No. KNA4-1-2, 19-7). And we would like to thank Editage (www.editage.co.kr) for English language editing.

Received: September 28, 2020, Revised: October 23, 2020, Accepted: October 29, 2020

First author: Jiwon Park, apfhdpjy@naver.com, (1) https://orcid.org/0000-0003-4345-5147

*Corresponding author: Miae Jeong, miaejeong630@korea.kr, (10) https://orcid.org/0000-0002-1242-7859 
health of the urban ecosystem, constantly highlighting the importance of forming green spaces in the city (Fuller et al., 2007; Goddard et al., 2010; Savard et al., 2000).

Recently, there has been an increase in the number of urban residents who wish to relax and feel the familiarity of nature in their daily residential and living spaces. This has led to a growing social interest in urban gardens. In particular, gardens in modern cities are prioritizing 'places where participation is valued' by growing plants, placing an emphasis on 'places to recover community life' with local residents, creating 'places with a productive function' by maintaining crops people raised themselves (Guitart et al., 2014; Martin et al., 2017), having 'places that give mental peace' through contact with nature (Kim and Lee, 2013; Lee, 2011; Nordh and Ostby, 2013), and forming 'alternative greenery' to support the city's ecological network and biodiversity (Goddard et al., 2010; Sierra-Guerrero and Amarillo-Suárez, 2017; Speak et al., 2015). Therefore, urban gardens must be understood from a public point of view, in that they are part of the community open space movement wherein urban residents build their own gardens in their own neighborhoods, traversing beyond the meaning of forming a physical space (Cho et al., 2007).

This study investigated the physical and social benefits that can be obtained by forming urban gardens. The study also aimed to figure out and compared the types of benefits from these urban gardens in Korea and overseas. The tendency of benefits in garden typology that can be applied to urban areas and using them for decision-making and creation of garden culture were also investigated.

\section{Research Methods}

To focus on how studies on gardens are conducted, we set academic dissertations and theses as the subject, and searched for articles published from 1998 to 2019 using
Research Information Sharing Service (RISS), Nurimedia (DBpia), Korean Studies Information Service System (KISS), National Digital Science Library (NDSL), and Korea Citation Index (KCI) in Korea, and ScienceDirect, SCOPUS, Springer, Wiley, and Taylor \& Francis from the overseas academic database. "Jeongwon ('garden' in English)," "gadeun (the English word 'garden' transliterated to Korean)," and "dosi ('city' in English)" were set as the keywords for Korean articles, and "urban," "garden," and "green" for overseas articles. We analyzed the articles obtained through searches of these word combinations to determine the research trend in urban gardens in Korea and overseas (Table 1).

Out of the total of 119 articles from Korea and 151 articles from overseas, the ones with main topics related to parks $\left(3,000 \mathrm{~m}^{2}\right.$ or bigger), urban planning, vacant lots (public open space, idle lands), rural gardens, and garden expositions were excluded, leaving 63 Korean articles and 90 overseas articles related to urban gardens that were deemed suitable for the purpose of this study.

Articles were read by the researcher and their topic keywords and key findings were identified. Key findings of the articles were grouped initially into major key findings (multidimensional concepts) and minor key findings (specific concepts that contributed to the major theme). First, the major key findings were set, based on the analysis of the garden divided into 'spatial composition' and 'social function' in the preceding study case (Shin and Choi, 2018) and the fact that the garden has great advantages in terms of 'ecology' and 'health' (Lee and Park, 2018). Among the articles, references to the legal system and the operation plan were divided into 'administration' separately. The classification of the major key findings was chosen in consideration of its relationship with the detailed theme: ecology to ecological elements, spatial composition to place elements, health to psychological and physical health, social function to public service, and administration. The minor key findings which contributed to major key findings

Table 1. List of keywords and word combinations for article search in Korea and overseas

\begin{tabular}{cll}
\hline Classification & Keyword & \multicolumn{1}{c}{ Word combination } \\
\hline \multirow{2}{*}{ Korea } & jeongwon(garden), gadeun (garden), dosi (city) & jaesaeng (regeneration), gongdongche (community), keomyuniti (the \\
& & English word 'community' transliterated to Korean), ogsang (rooftop) \\
Overseas & urban, garden, green & space, roof(top), community, allotment, pocket, small, edible, vegetable \\
\hline
\end{tabular}


were grouped: biological and non-biological elements (such as vegetation, microclimate, water and soil) into ecological elements; spatial functions such as landscaping or garden structure into place elements; personal benefits that can be obtained from gardens (e.g. mental or physical health and satisfaction) into psychological and physical health; benefits or effectivity for public such as welfare, education, food production or security, and economic benefits into public service; and policies, systems, and management guidelines into administration. Ecological elements and place elements were grouped into physical environments, and external conditions that could affect humans (National Research Council, Institute of Medicine, 2013). Psychological and physical health, public service and administration were grouped into social environment, which includes elements of social participation, social cohesion and social capital (National Research Council, Institute of Medicine, 2013) (Fig. 1).

\section{Results and Discussion}

\section{Definition of gardens and proportion of key findings in Korea and overseas articles}

Gardens are places that have continuously been part of the human residential environment, and are perceived as spaces in which human activities are carried out, from pri- vate spaces to public open spaces like parks (Woo and Suh, 2016). Gardens created as a green space within the sphere of human living are tended to and cultivated by citizens in their daily lives in various parts of the city. These can be created as a space with an unconstrained form, familiar shape and practicality through the leisure activities of citizens (Sim and Zoh, 2015). Urban gardens involve planting various kinds of plants in the city. They may also involve the establishment of a relevant environment in the city, comprehensively indicating that gardens form part of said city (Ernwein, 2014). Urban gardens that appear to be an efficient use of space in small land are extremely small pieces of green space that trigger interactions among local residents, building an urban image of gardens created in a complex structure (Sim and Zoh, 2015).

According to Table 2, physical environment $37.73 \%$ and social environment $62.27 \%$ were studied in garden-related articles in Korea and overseas. Through a comparison of Korean and overseas articles, it was found that in Korea more articles were focused on place elements and psychological and physical health, while overseas more articles were focused on ecological elements, public service and administration. Key findings of Korean and overseas studies on the physical and social environment of gardens and green spaces in the city are as shown in Table 3, Table 4 and Fig. 2 below.

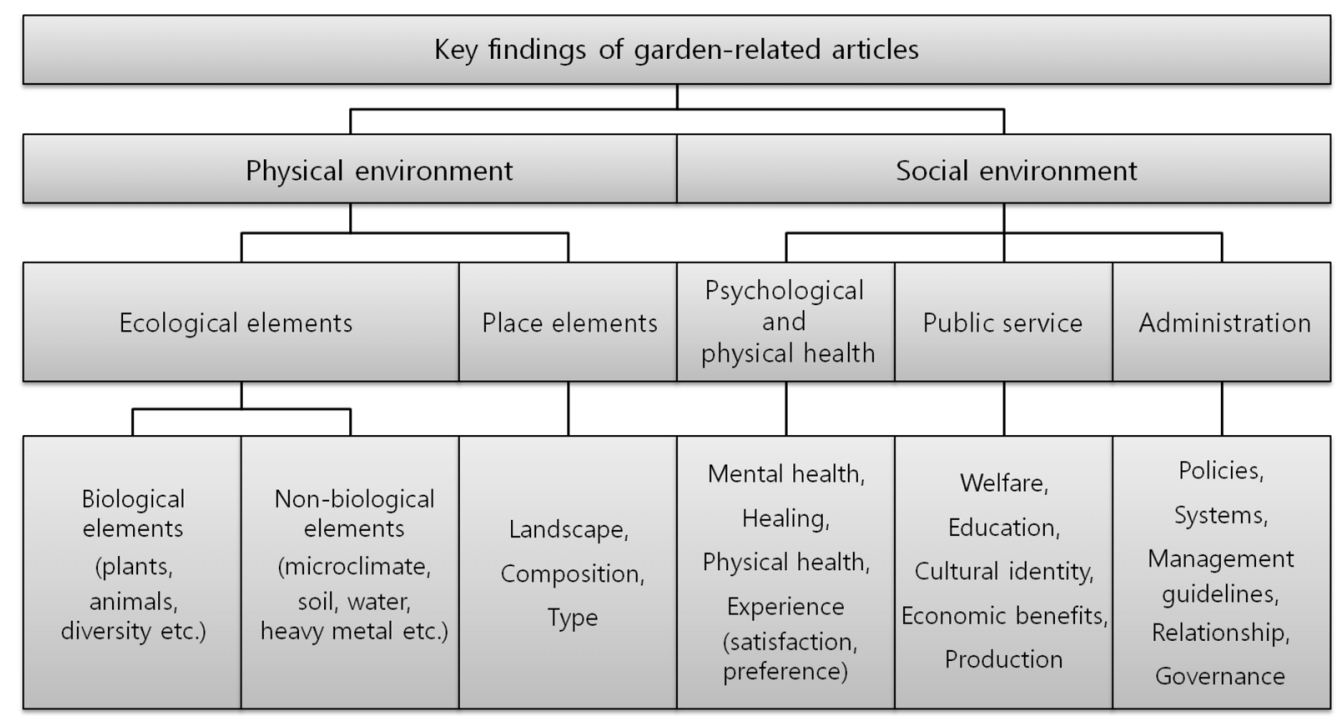

Fig. 1. Classification of garden-related articles by key findings of articles in Korea and overseas. 
Table 2. Proportion of garden-related articles by key findings of articles in Korea and overseas

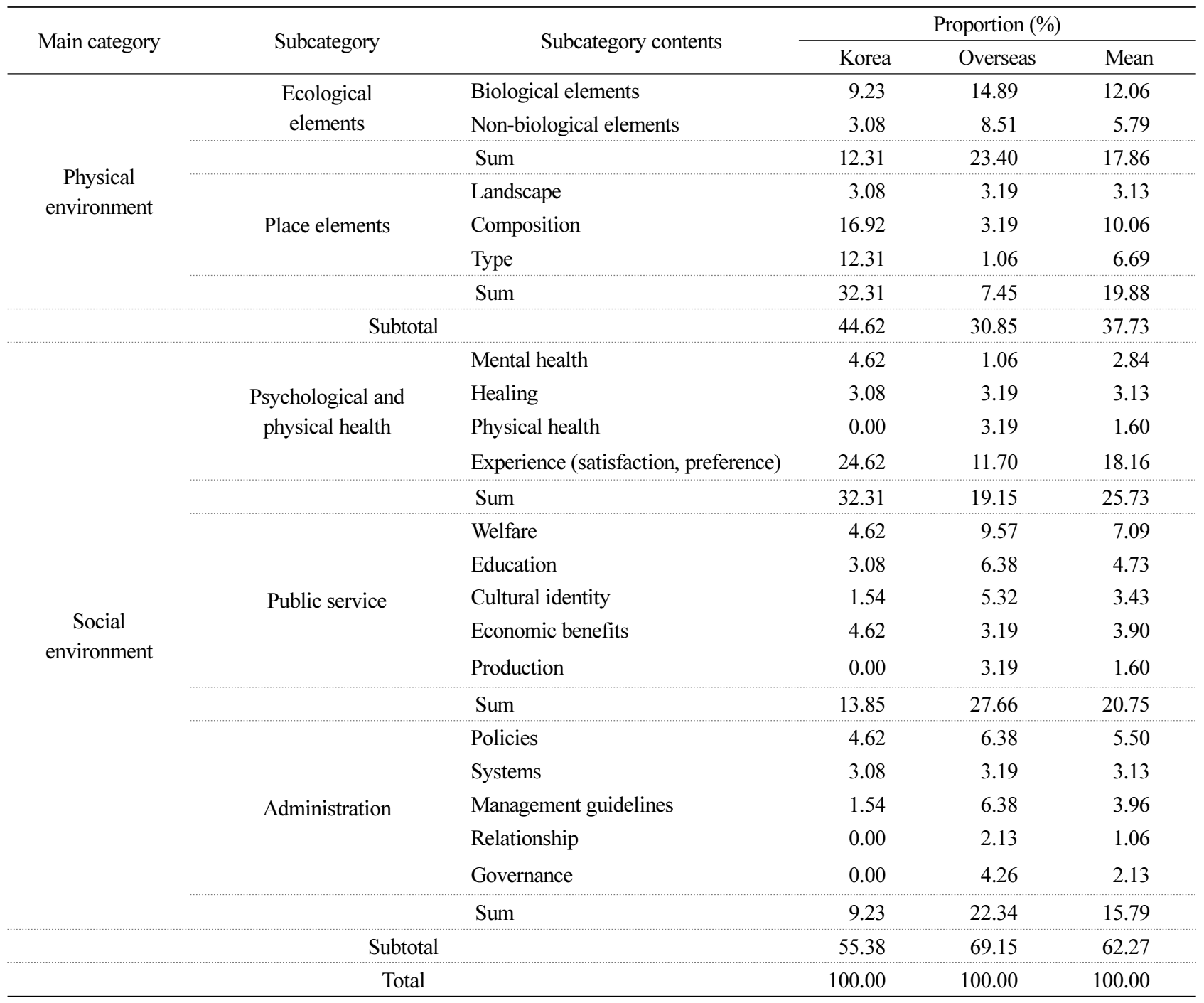
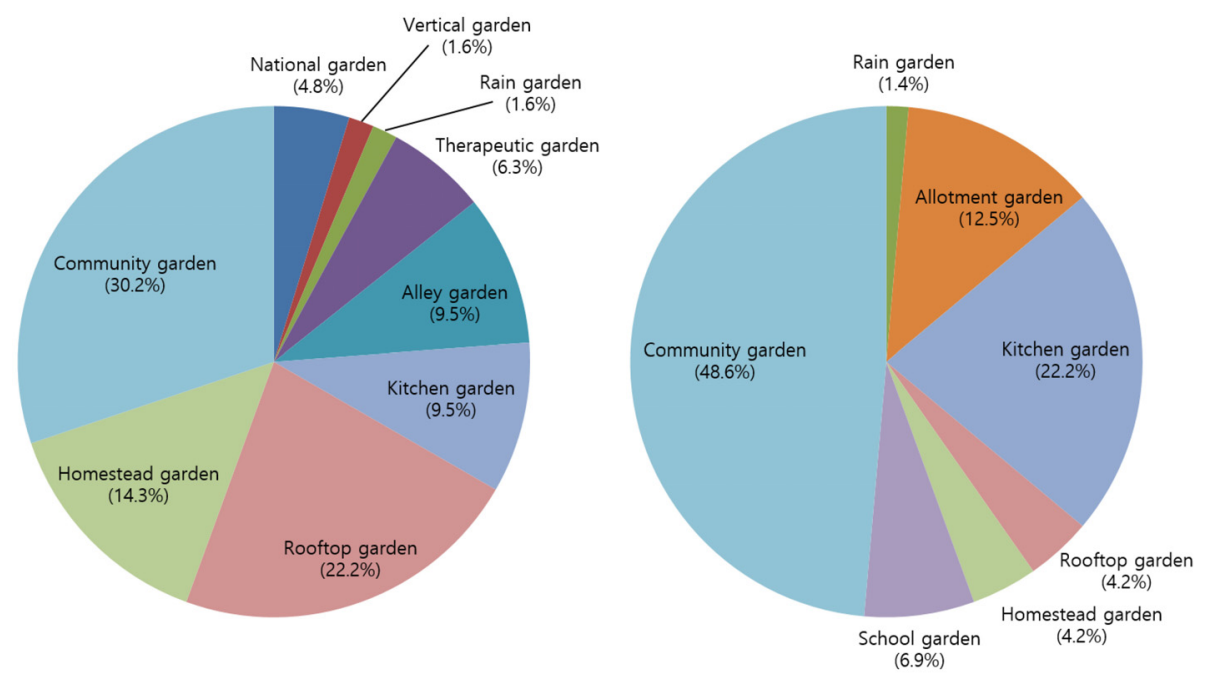

Fig. 2. Types and ratio of gardens studied in Korean and overseas articles (left: Korea; right: Overseas). 
Table 3. Key research findings in Korea and overseas related to physical environment

\begin{tabular}{|c|c|c|c|}
\hline Category & Author & Research method & Key findings \\
\hline \multirow{4}{*}{$\begin{array}{c}\text { Place } \\
\text { elements }\end{array}$} & $\begin{array}{l}\text { Choi et al. } \\
\text { (2017) }\end{array}$ & $\begin{array}{l}\text { Selected target sites in Yeoksam-dong, } \\
\text { Gangnam-gu. Analyzed landscape index } \\
\text { through FRAGSTATS and classified green } \\
\text { spaces through object-oriented classification. } \\
\text { Assessed green space connectivity by } \\
\text { generating multiple buffers. }\end{array}$ & $\begin{array}{l}\text { Green areas are distributed in the order of street greenery } \\
34.1 \% \text {, private gardens } 22.2 \% \text {, remnant vacant lots } \\
20.1 \% \text {, parks } 14.9 \% \text {, and rooftop gardens } 8.8 \% \text {. } \\
\text { Connection contribution by type of green space was in } \\
\text { the order of remnant vacant lot, street greenery, private } \\
\text { garden, roof garden, and park. }\end{array}$ \\
\hline & $\begin{array}{l}\text { Sim and Zoh, } \\
\quad(2015)\end{array}$ & $\begin{array}{l}\text { Haebangchon, autonomous urban residential } \\
\text { area, is the spatial subject. Literature review, } \\
\text { regional observation, and in-depth interviews } \\
\text { with residents. }\end{array}$ & $\begin{array}{l}\text { Practical }(37 \%) \text { and Aesthetic }(63 \%) \text { type of urban } \\
\text { garden. Flexible type }(76 \%) \text { which can move in narrow } \\
\text { yards and cross-space and occupies a minimum area, } \\
\text { accounted for a higher percentage than fixed type }(21 \%) \text {. }\end{array}$ \\
\hline & $\begin{array}{l}\text { Sung and Lee, } \\
\qquad(2013)\end{array}$ & $\begin{array}{l}\text { Compared spatial characteristics (public } \\
\text { interest, design, usability) of cases in Korea } \\
\text { and overseas. }\end{array}$ & $\begin{array}{l}\text { Overseas: Maintained in places where enough public } \\
\text { space can be secured, such as a big open space or space } \\
\text { in the park. Korea: Simple spatial composition of } \\
\text { rectangular land module formation. }\end{array}$ \\
\hline & $\begin{array}{l}\text { Belmeziti et al. } \\
\qquad \text { (2018) }\end{array}$ & $\begin{array}{l}\text { Literature review: classified green spaces by } \\
\text { goals, classification criteria and types, and } \\
\text { came up with green space components. } \\
\text { Case study: Categorized green spaces in } \\
\text { Campus La Doua, France. }\end{array}$ & $\begin{array}{l}\text { Classifying the components of urban green spaces into } \\
\text { tree, shrub, herbaceous, floral, mineral, aquatic, } \\
\text { temporary water, mulch, and agricultural field. } 17 \text { out of } \\
28 \text { types of green space components, with grass taking } \\
\text { up } 47 \% .17 \text { out of } 21 \text { types of urban service. }\end{array}$ \\
\hline \multirow{4}{*}{$\begin{array}{l}\text { Ecological } \\
\text { elements }\end{array}$} & $\begin{array}{l}\text { Fuller et al. } \\
\text { (2007) }\end{array}$ & $\begin{array}{l}\text { Calculated } 15 \text { green spaces in cities with } \\
\text { various residential types from the developed } \\
\text { urban center with high density to the suburbs } \\
\text { with low density. Examined species richness } \\
\text { in the randomly extracted quadrat of herbaceous } \\
\text { ornamentals } 1 \mathrm{~m}^{2} \text {, woody plants } 10 \mathrm{~m}^{2} \text {. }\end{array}$ & $\begin{array}{l}\text { Classified green spaces into } 15 \text { types such as parks, } \\
\text { gardens, schools, and street spaces. Park area had a } \\
\text { positive correlation with the number of habitat type, but } \\
\text { not with plant richness. The number of habitat type had a } \\
\text { positive correlation with plant richness }\end{array}$ \\
\hline & $\begin{array}{l}\text { Speak et al. } \\
\text { (2015) }\end{array}$ & $\begin{array}{l}\text { Examined native plant species in allotment } \\
\text { gardens of two cities, Manchester in England } \\
\text { and Poznan in Poland, and compared them } \\
\text { with parks. }\end{array}$ & $\begin{array}{l}\text { Parks have approximately } 65 \% \text { species richness } \\
\text { compared to allotment gardens, whereas allotment } \\
\text { gardens have at least } 2.5 \text { times higher species richness of } \\
\text { native plants. }\end{array}$ \\
\hline & $\begin{array}{l}\text { Goddard et al. } \\
\qquad(2010)\end{array}$ & $\begin{array}{l}\text { Conducted a case study on gardens of } \\
\text { advanced countries such as the US, UK, } \\
\text { Canada, New Zealand, etc. }\end{array}$ & $\begin{array}{l}\text { Small gardens can serve as habitats to preserve } \\
\text { biodiversity in the city and function as green corridors } \\
\text { forming an ecological network. }\end{array}$ \\
\hline & $\begin{array}{l}\text { Sierra-Guerrero and } \\
\text { Amarillo-Suárez } \\
\text { (2017) }\end{array}$ & $\begin{array}{l}\text { Examined biodiversity of } 70 \text { gardens in } 7 \\
\text { areas of Bogota, Colombia. }\end{array}$ & $\begin{array}{l}\text { Discovered } 82 \text { genera, } 240 \text { species and } 4,110 \text { individuals. } \\
\text { Found that mean species richness of gardens was } 15.4 \text {. } \\
\text { Species richness increased in older gardens }\end{array}$ \\
\hline
\end{tabular}

\section{Comparative analysis on characteristics of gardens in Korea and overseas}

According to Fig. 2, of the types of urban gardens studied, community gardens represented the highest portion both in Korea and overseas, with the percentage nearing $50 \%$ overseas.

Community gardens literally are "gardens in the community or neighborhood in which one lives." These are gardens for the neighborhood, and form a community by ex- tending the fences to the neighborhood. Emphasizing neighborhood gardens connotes the meaning of "shared gardens for the community." Neighborhood gardens are characterized by people in the neighborhood sharing the place to enjoy, and not to possess nature on their own (Sung and Lee, 2013). Community gardens are known to not only cultivate crops and improve and protect urban spaces, but also to contribute to the formation and strengthening of the community based on cooperation among residents of all races and generations (Park et al., 2011). Because of 
Table 4. Key research findings in Korea and overseas related to social environment

\begin{tabular}{|c|c|c|c|}
\hline Category & Author & Research method & Key findings \\
\hline & $\begin{array}{c}\text { Kim and Lee } \\
\text { (2013) }\end{array}$ & $\begin{array}{l}\text { Extracted samples with 1:1 interview using } \\
\text { a questionnaire that combined items of } \\
\text { effectiveness measurement, as well as with } \\
\text { quota sampling. } \\
\text { Items of effectiveness measurement: Perceived } \\
\text { Restorativeness Scale(PRS), community spirit. }\end{array}$ & $\begin{array}{l}\text { Those participating in community gardens, living closer } \\
\text { to community gardens, and can see community gardens } \\
\text { from their residence tended to show greater psychological } \\
\text { and social effects such as psychological well-being, } \\
\text { stress, life satisfaction, interaction with neighbors, and } \\
\text { crime prevention. }\end{array}$ \\
\hline & $\begin{array}{c}\text { Jang et al. } \\
\text { (2017) }\end{array}$ & $\begin{array}{l}\text { Survey on importance and satisfaction of } \\
\text { components with } 127 \text { residents (5-point } \\
\text { Likert scale), IPA analysis. }\end{array}$ & $\begin{array}{l}\text { Items on safe and clean environment showed high } \\
\text { importance. Items improved residential environment such } \\
\text { as "installation of lighting facilities," 'amount and type of } \\
\text { herbaceous ornamentals," showed high satisfaction but } \\
\text { satisfaction with resident amenities was low. Components } \\
\text { of alley gardens were categorized into } 4 \text { factors such as } \\
\text { 'safety and cleanliness', 'greenness', 'urban aesthetics } \\
\text { arrangement', and 'interaction and amenities', all of } \\
\text { which had a significant effect on overall satisfaction. }\end{array}$ \\
\hline
\end{tabular}

Psychological and Physical health Lee (2011)

$\begin{array}{ll} & \text { experience scale. } \\ \text { van den Berg et al. } & \begin{array}{l}\text { Conducted a survey among } 121 \text { members of } \\ \text { (2010) }\end{array} \\ & \begin{array}{l}\text { respondents without an allotment garden } \\ \text { near the home. }\end{array}\end{array}$

Assessed capability of being restored with

Nordh and Ostby images of 74 parks (less than $3000 \mathrm{~m}^{2}$ ) with

(2013) college students aged 29 on average $(\mathrm{N}=58)$ (scale of 0-10 points).

Martin et al.

(2017)

(2018)

Public service

Egli et al.

Presented 10 photos each of cities, rooftop Perceived Restorativeness Scale (PRS), attention restoration scale, transcendent

Estimated the amenity value of urban green spaces using housing prices. Conducted a choice experiment that assessed non-market value through formation of a virtual market and hedonic pricing focused on the real estate market. gardens and forests to 221 college students. The total mean of three psychological indicators was Measured psychological indicators through highest for forests, followed by rooftop gardens and cities. Rooftop gardens can provide as many psychological benefits as forests.

Allotment gardeners indicated $12 \%$ higher levels of physical activity than neighbors in summer.

The impact of gardening on health and well-being were increased with age.

Among categories contributing to high scores about capability of being restored, abundant grass was most frequently mentioned, followed by abundant flowers/plants, water function. The most frequently mentioned activity was relaxing and thinking philosophically.

Interviewed gardeners and examined Preferred diversity, taste, and health of products. amount of harvest in 5 community gardens Households with gardeners showed high supply of fruits close to houses in Marseille, France. and vegetables.

Discovered that when there was a green space (forest, stream, park) within a 10-minute walk, the housing had $18 \%$ (KRW 3.2 million/year) higher value on average if it is an apartment, and $20 \%$ (KRW 4.8 million/year) if it is a detached house.

Nutritional health environment: fruit and vegetable consumption and the impact of social network help residents maintain a healthy weight, have contact with nature and carry out regular activities for active physical activities, it aids them into bringing economic benefits and shortening of the supply chain in terms of food supply. Social health environment: community gardens reduce crimes and stress, making residents feel ownership and pride, have positive effects on urban aesthetics through citizen participation and political activities, and have residents share cultural identity as well as goals and experiences, thereby affecting community cohesion 
Table 4. (continued)

\begin{tabular}{|c|c|c|c|}
\hline Category & Author & Research method & Key findings \\
\hline \multirow{4}{*}{ Public service } & $\begin{array}{l}\text { Sampaio et al. } \\
\qquad(2018)\end{array}$ & $\begin{array}{l}\text { Examined the effects of contact with forests } \\
\text { on knowledge about biodiversity with } 267 \\
\text { students in grades } 1-5 \text { according to distance } \\
\text { between forest and school (less than } 500 \mathrm{~m} \text {, } \\
\text { more than } 5,000 \mathrm{~m} \text { ), and assessed } \\
\text { knowledge through drawings of forests }\end{array}$ & $\begin{array}{l}\text { For participants with little contact with the forest, } \\
\text { components related to humans took up } 10 \% \text { of the } \\
\text { drawings, whereas those with more contact with the urban } \\
\text { forest tended to draw more local animals, which proved that } \\
\text { proximity to the natural environment induces interest in } \\
\text { components of green spaces even in the urban environment } \\
\text { and helps establish the foundation for knowledge building }\end{array}$ \\
\hline & $\begin{array}{l}\text { Algert et al. } \\
\text { (2014) }\end{array}$ & $\begin{array}{l}\text { Measured output for } 4 \text { months in } 18 \\
\text { community gardens }\end{array}$ & $\begin{array}{l}\text { Gardeners saved } \$ 435 \text { on average in } 4 \text { months. Community } \\
\text { gardens are more similar to biointensive high-production } \\
\text { farming than conventional agricultural practice }\end{array}$ \\
\hline & $\begin{array}{l}\text { Martin et al. } \\
\text { (2017) }\end{array}$ & $\begin{array}{l}\text { Interviewed gardeners and examined } \\
\text { amount of harvest in } 5 \text { community gardens } \\
\text { close to houses in Marseille, France }\end{array}$ & $\begin{array}{l}\text { Preferred diversity, taste, and health of products } \\
\text { Households with gardeners showed high supply of fruits } \\
\text { and vegetables }\end{array}$ \\
\hline & $\begin{array}{l}\text { Wang et al. } \\
\text { (2014) }\end{array}$ & $\begin{array}{l}\text { Marked the locations of supermarkets, } \\
\text { community gardens and farmers' markets } \\
\text { on a map } \\
\text { Assessed food accessibility along with } \\
\text { demographics and socioeconomic } \\
\text { characteristics }\end{array}$ & $\begin{array}{l}\text { The closest food access distance was reduced from } 1.76 \mathrm{~km} \\
\text { to } 1.44 \mathrm{~km} \text { on average after implementing community } \\
\text { gardens and farmers' markets. Community gardens } \\
\text { tended to concentrate on densely populated areas, and } \\
\text { supermarkets and community gardens were distributed in } \\
\text { areas with relatively low median income }\end{array}$ \\
\hline \multirow[b]{2}{*}{ Administration } & $\begin{array}{l}\text { Teig et al. } \\
\text { (2009) }\end{array}$ & $\begin{array}{l}\text { Conducted individual and group interviews } \\
\text { with residents who participated in } \\
\text { community gardens }\end{array}$ & $\begin{array}{l}\text { Activation of community gardens requires the right place } \\
\text { for them as well as the foundation for social organizations. } \\
\text { Affected social relations, decision making, citizen } \\
\text { participation and promotion of health. }\end{array}$ \\
\hline & $\begin{array}{l}\text { Fox-Kämper et al. } \\
\qquad(2018)\end{array}$ & $\begin{array}{l}\text { Review on scholarly literature of community } \\
\text { garden governance and } 82 \text { articles were } \\
\text { selected. } \\
\text { Case study on New Zealand and German } \\
\text { community gardens. }\end{array}$ & $\begin{array}{l}\text { Top-down (completely managed by professionals without } \\
\text { community representative in the management committee), } \\
\text { top-down with community help (planned, established or } \\
\text { managed by professionals with the participation of the } \\
\text { community), bottom-up with professional help (established } \\
\text { and managed by the community with the help of } \\
\text { professionals), bottom-up with informal help (participation } \\
\text { of informal professionals), bottom-up (run almost } \\
\text { exclusively by the community), and bottom-up with political } \\
\text { and/or administrator support (planned, implemented and } \\
\text { managed by the community supported by the government) }\end{array}$ \\
\hline
\end{tabular}

this, the attention to community gardens is received thereby. Urban community gardens are mostly formed in the middle of the city or suburban areas, and can be categorized into neighborhood living type (located within walking sphere including private land), idle land utilization type (remnant land, vacant land, street greenery, etc.), residential complex type (detached housing or apartment district), and base connection type (parks or public facilities) (Choi et al., 2018). In 2014, average green area per capita of 29 OECD countries was $520.41 \mathrm{~m}^{2}$, with Korea ranking $26^{\text {th }}$ for green space at $57.91 \mathrm{~m}^{2}$ per capita (United Nations Human
Settlement Programmes, Global Urban Observatory, 2018). Moreover, other countries tend to divide and use sections where enough public space can be secured, such as big open spaces or park spaces. On the other hand, Korea tends to form rectangular land modules as a simple space (Sung and Lee, 2013). In the densely integrated residential space in Korea, the gardens can be moved in narrow yards and street spaces, and flexible type (76\%) gardens that occupy a minimum area are found to be more common than the fixed type (21\%) (Sim and Zoh, 2015) (Table 5). The governance structure of urban community gardens can be clas- 
Table 5. Images of gardens in Korean and overseas (refer to Image credits).

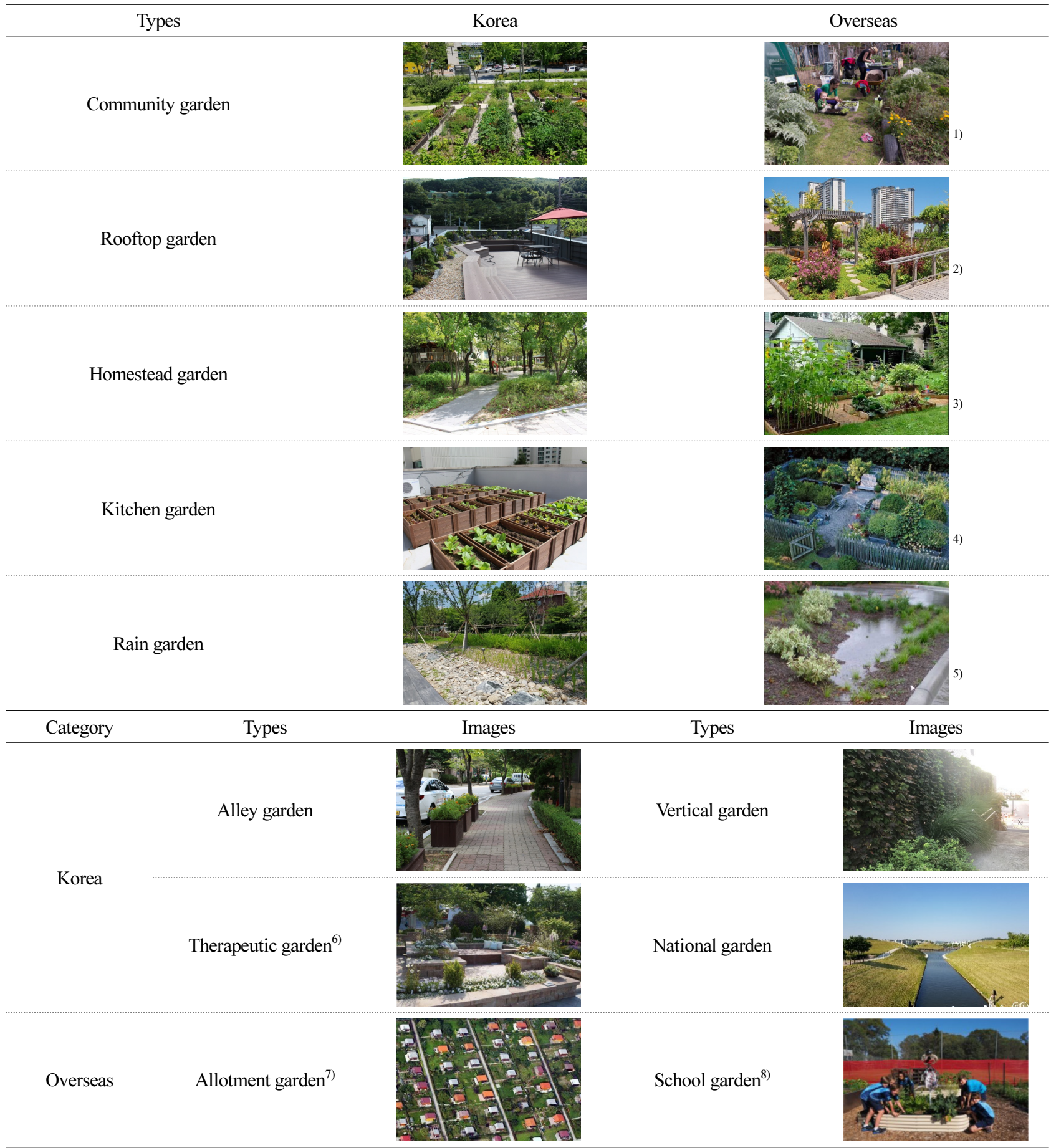

Note. Date for 1) from Fox-Kämper (2018), for 2) from Hoff (2016), for 3) from Long (n. d.), for 4) from Morris (2013), for 5) from Park (2014), for 6) from Riley (2017), for 7) from Samantha (2019), and for 8) from Yard and garden extension (2018).

sified into 6 types (Table 4). To use community gardens to activate social capital and promote community elasticity, a bottom-up governance structure with good connection and management will be the most effective, and will be successful as long as the community has the motives and can secure sufficient public funds and support (Fox-Kämper et al., 2018). The Sydney guidelines specifically provided facilities that can be applied according to the size and the 
number of people needed (up to $100 \mathrm{~m}^{2}, 15$ or more; around $400 \mathrm{~m}^{2}, 25$ or more; $1,000 \mathrm{~m}^{2}$ or more, 40 or more) in the community gardens (City of Sydney, 2016). In the Korea guidelines, size (up to $100 \mathrm{~m}^{2}, 101-200 \mathrm{~m}^{2}, 201-400 \mathrm{~m}^{2}$, $400 \mathrm{~m}^{2}$ or more) and participants (under 5, 6-10, 11-20, 21-30, 30 or more) were found in the checklist, but there was no specific explanation (Rural Development Administration, National Institute of Horticultural and Herbal Science, 2020). In the Act on the creation and furtherance of arboretums and gardens, an area of $300,000 \mathrm{~m}^{2}$ was proposed as a requirement for designation of a national garden (National Law Information Center, 2019a). According to agricultural laws, garden sizes were up to $400 \mathrm{~m}^{2}$ in Germany, up to $300 \mathrm{~m}^{2}$ in the U.K., $10-30 \mathrm{~m}^{2}$ or 100-300 $\mathrm{m}^{2}$ in Japan (Hwang, 2010). The size of a garden for operating an urban agricultural community was suggested to be $100 \mathrm{~m}^{2}$ or more in Korea (National Law Information Center, 2019b). As such, it is necessary to present standards for creating communities through gardens in the Act on the creation and furtherance of arboretums and gardens based on overseas cases and the Act on the development and support of urban agriculture.

The second-highest portion was taken up by rooftop gardens in Korea and kitchen gardens overseas. In addition, there are differences in the types of gardens studied in the papers, such as alley gardens, therapeutic gardens, national gardens, vertical gardens in Korea, and allotment gardens in overseas (Fig. 2).

Rooftops and roofs capable of green planting in Seoul take up approximately $70 \%$ of the city, which shows the possibility of rooftop gardens. This also suggests that roofs can supplement the lack of green space, solve the city's ecological and environmental problems, and even become cultural spaces (Lee et al., 2014). Thus, this result reflects the enthusiasm in using rooftop gardens. Vertical gardening is one of the most useful ways to expand urban green space by covering the walls of buildings or other structures with trees or flowers. Rooftop and vertical gardens can be a very effective alternative to increasing the urban greening rate if the artificial greening method is applied to buildings that are available from the overall perspective of the city, even if the area of the artificial greening by each building is not large (Park, 2012). As the rural population gathered into big cities in the 1960s, leading to a severe housing shortage, apartments were chosen as a method to increase residential density in limited land space (Lee et al., 2017). Currently, apartments represent $49.2 \%$ of all housing in Korea (Korean Statistical Information Service, 2019). Certain side effects resulted from the fact that urban neighbors were strangers to one another, unlike in rural communities where neighbors were mostly family and close relatives along with and lived together in the same area. One paper stated that a person was hit and killed by an object that fell from the upper floors down to the ground, the desolate and artificial environment surrounded by concrete causes psychological problems such as depression, and inter-floor noise complaints was frequently caused in apartments (Lee et al., 2017). Recently, amenity has been the highest priority among apartment considerations, apartment complexes with a view of nature such as parks, forests or rivers are preferred, and community spaces that had merely been providing exercising or learning facilities are now turning into places where the whole family or residents can enjoy leisure together (Park, 2019). Apartment residents desired social interaction rather than an isolated form of living that emphasizes anonymity, highlighting the necessity of shared spaces for the purpose of promoting mutual interaction (Kim et al., 2010). The trend in new apartments is taking the form of public gardens where they have a park or gardening facility 2.5 times bigger than a soccer field. They also use $40 \%$ of the complex area for landscaping, allowing the residents to tend gardens on part of the expanded space of the living room balcony. In addition to these, they also have a themed garden walkway. Moreover, places with increased residential amenity can also anticipate huge profits when selling the apartment (Jung, 2019a, 2019b; Lee, 2019).

Overseas, gardens have spread out in the UK, Europe, and North America to make up for food shortages during war, playing a key role in national food security by providing essential nutrients that could not be supplied by the environment at the time (Egli et al., 2016; Ginn, 2012). Because of this, gardens have been developed with an emphasis on food supply for low-income groups, which is why many studies overseas are on kitchen gardens. Allotment gardens also have been shown throughout history to pro- 
vide long-term food security in times of energy scarcity (Barthel and Isendahl, 2013), and average allotment garden area was 1.2 ha in Manchester (UK) and 10.2 ha in Poznan (PL) (Speak et al., 2015). Social inequality in the area of food is caused by sociocultural determinants, economic constraints, and unequal access to healthy food. Thus, the dietary formula of low-income groups lacks fruits and vegetables (Martin et al., 2017). A "food desert" is an area that lacks accessibility to affordable and nutritious food, and these can be found in cities and rural areas of North America. Community gardens provide group members and other residents with fresh vegetables and fruits, contribute to making a healthy dietary pattern, and reducing health risks (Wang et al., 2014). They also help students have a healthy diet of vegetables and fruits, while changing their dietary habits and knowledge about food production. Various plants of 66 genera and 159 species were discovered at community gardens in school built for education, health, and environmental sustainability (Guitart et al., 2014). Households that include gardeners tended to use more diverse agricultural products than those that do not (Martin et al., 2017). Gardening activities in community or school gardens are affordable and practical methods to secure safe food supply and improve health for urban residents and students.

Korea has come to focus on the rooftop space due to its small land area, and the most common residential type is multi-unit buildings like apartments, with public gardens formed within the complex. In other countries, people promote health by carrying out gardening activities combined with kitchen gardens and by producing safe vegetables and fruits. It is a global trend to harmonize the residents with gardens and promote recovery of the community. As such, it is necessary to form gardens, including kitchen gardens in rooftops or apartment complexes, and run them in the form of community gardens in which all residents can participate together.

\section{Benefits of urban gardens in terms of physical environment}

Creating a new urban park over a certain size involves many difficulties, which can include compensation for stakeholders regarding the existing building or land as well as a large budget and time investment. As such, the alternative is to build green space networks by forming small green spaces within the neighborhood such as gardens. To preserve urban biodiversity, small gardens in addition to parks can also serve as habitats as extensive and unique resources. They may also function as green corridors that form an ecological network (Goddard et al., 2010). Green spaces in a city with high biodiversity provide greater physical and psychological benefits for the public, and can even increase the resilience of the urban environment (Fuller et al., 2007). For this reason, building a green space network by forming small green spaces and securing connectivity is being considered an important initiative for creation and management of urban green spaces (Han et al., 2014).

A connectivity assessment was conducted on green space networks by classifying the green spaces of a built-up area with high density in Korea, and it was found that green spaces in the target site were distributed in the order of street greenery, private garden, remnant vacant lot, park, and roof garden. Remnant vacant lots and street greenery were the spaces with highest potential for green corridors (Choi et al., 2017), and $20 \%$ of the cases were found in public areas of streets, following private areas inaccessible from the outside such as rooftop gardens or terraces (33\%) (Sim and Zoh, 2015). This reflects the traditional view of life in streets, in which some people still extend their living space out to the streets, although this has decreased since urbanization began. This implies that small gardens using remnant vacant lots and street greenery can improve accessibility to green space.

Looking at green spaces of campus in France, 1/3 were simple green spaces $(32 \%)$ with just one type of component, whereas the rest had two or more components of green spaces (68\%). Urban services in the campus green spaces are classified into water management, use of space, improvement of biodiversity and well-being, and all urban services related to promoting biodiversity are provided by the green infrastructure on campus, thereby showing a great potential for important biodiversity (Belmeziti et al., 2018). In general, studies in Korea have tended to categorize urban green spaces with a focus on space, whereas overseas studies have focused on the components of green space and 
analyzed urban services accordingly.

An allotment garden is one form of service to provide rights to use an accessible place near residence at a low cost for citizens or the community and induce cultivation of vegetables and social interaction (Kim, 2011). Allotment gardens had higher plant species richness than parks (Table 3 ). This may be due to the difference in the land management customs between parks and allotment gardens - since parks weed regularly, the number of species that can survive might be limited (Speak et al., 2015). Moreover, an investigation of the biodiversity of 70 gardens in Colombia led to the discovery of a total of 82 genera, 240 species, and 4,110 individuals. Furthermore, the average species richness of the gardens was 15.4, with older gardens showing higher species richness (Sierra-Guerrero and Amarillo-Suárez, 2017). In the UK, plant richness varied depending on the size of green space. This shows the measurable positive correlation between the rich species of urban green spaces and the well-being of visitors. Psychological benefits were positively correlated with plant species richness and birds, and such benefits increased in green spaces where plants' and birds' richness is generally high (Fuller et al., 2007). Bird diversity in urban areas tends to be proportional to the volume of existing vegetation (Savard et al., 2000).

It is difficult to secure green planting space in urban centers with high building coverage; green space networks can be built in a city by creating small green spaces within the living zone. It is effective to build gardens for small green spaces using street space, remnant vacant lots and rooftops. Moreover, more diverse plant species can inhabit gardens than parks, which promotes biodiversity and thus has a positive effect on the health of the urban ecosystem. As a consequence, small spaces such as a vacant lot, pocket of land, or a rooftop can be used to build gardens in Korea, which would be used as a base reference to promote the reasonable values of garden construction. In addition, if a feasible guideline is produced in order to utilize a small size vacant land in a productive way, it should be adopted through supportive legislation by the municipalities to apply an approval of promotion policy.

\section{Benefits of urban gardens in terms of social environment}

Community gardens can help residents maintain a healthy weight, promote physical activities, secure food supply, increase their ownership and pride in the region, and support urban aesthetics and community cohesion (Egli et al., 2016).

High consumption of vegetables and fruits and improve regular physical activity and directly affect health, and garden activity is a form of physical exercise that offers benefits in the areas of fitness, health and well-being (Van den Berg et al., 2010; Kingsley et al. 2007), and can help prevent obesity in adults (Zick et al., 2013). Community gardens can provide fresh vegetables and fruits for group members and other residents, and can also resolve the aforementioned issue of food deserts (Wang et al., 2014). Food prices were high during the Cold War, so garden cultivation provided an alternative food supply, and helped stabilize the economy (Shin and Choi, 2018).

A therapeutic garden means a garden that draws energy to the body and vitality to the mind, ultimately bringing out the rhythm to restore the weak body and mind to its original state (Park and Lee, 2014). People who participated more in community gardens, lived closer to community gardens, and can see community gardens from their residences tended to show greater psychological and social benefits (Kim and Lee, 2013). The total mean of the three psychological indicators was the highest in forests, followed by rooftop gardens and cities. Considering that rooftop gardens have greater accessibility than forests, they may be more excellent than forests in terms of their positive effects on mental and physical health of urban residents in everyday life (Lee, 2011). Moreover, proximity to the natural environment induces interest in components of green spaces, even in the urban environment, and helps establish the foundation for knowledge building (Sampaio et al., 2018).

Nordh and Ostby (2013) showed that small urban parks must be designed with natural components protected from the disturbance of surroundings, promote opportunities for restoration experience, and have certain seats to function as a venue for social encounters. To improve the alley environment, it was found that there was a need for a space 
for interaction and rest, and the satisfaction with the alley garden was also high (Jang et al., 2017).

Furthermore, community gardens are more similar to biointensive high-production farming than conventional agricultural practice (Algert et al., 2014), and thus may bring economic benefits through cost reductions. In Korea, when willingness to pay (maximum amount a buyer is willing to pay to own rather than to live without any product or service) was compared, classifying urban green spaces into mountains, forests, rivers, streams, lakes and urban neighborhood parks, it was found that when there was a green space within a 10-minute walk from the residence, housing had an $18 \%$ higher value on average for apartments, and a 20\% higher value for detached houses (Choi and Eom, 2018).

The result of PRS measurement was highest for forests, followed by rooftop gardens and cities. Items that contributed greatly to capability of being restored were natural elements such as grass, flowers, plants, and water. As such, citizens close to gardens showed high psychological well-being and life satisfaction as well as low stress, increased interaction with neighbors, and greater crime prevention effects. Gardens also have positive effects on urban aesthetics such as safety of alleys, cleanliness, and greening, as well as the issue of food deserts, producing significant psychological and social effects. Gardens have great accessibility to urban residents and provide as many psychological benefits as forests, and thus are efficient means to promote mental and physical health. Contact with green spaces such as gardens in the city is also an effective way for students to obtain knowledge about environmental components and biodiversity.

\section{Conclusion}

Through studying the previous research on urban gardens in Korea and overseas, it was found that in Korea, due to its narrow land area and complex urban structure, there was high interest in using rooftops, wall surfaces, and street spaces, and a tendency to arrange container-type flexible gardens. Apartment housing is the most common residential form, and thus public gardens in apartment complexes are on the rise. Overseas, the focus was on promot- ing health and reducing food inequality through gardening activities and safe vegetable and fruit production by the allotment and kitchen gardens, and this tended to use a larger area as a fixed form than Korea. As a result, this had a positive effect on urban biodiversity. To sum up, Korea's urban gardens tend to be close to living spaces with green areas in a complex urban structure, while overseas urban gardens influence an ecosystem focused on food production related with human health.

Gardens had beneficial effects on the physical environment $(37.73 \%)$ of cities and on the social environment $(62.27 \%)$ of urban residents (Table 2). Gardens in urban areas help preserve the ecosystem and promote biodiversity through physical connection with nature. They also help improve cities by promoting urban aesthetics. Moreover, people close to gardens enjoy psychological and physical benefits as well as educational effects. It is also possible to produce food in kitchen gardens and carry out gardening activities with others to promote social interaction, which contributes to the recovery of the community and has positive social effects as well (Fig. 3).

Continuous research is therefore needed to establish guidelines that are applicable to Korea in order to use gardens with high utility value that provide complex benefits to the community - such as activating social capital, boosting community resilience, and promoting the health of the ecosystem.

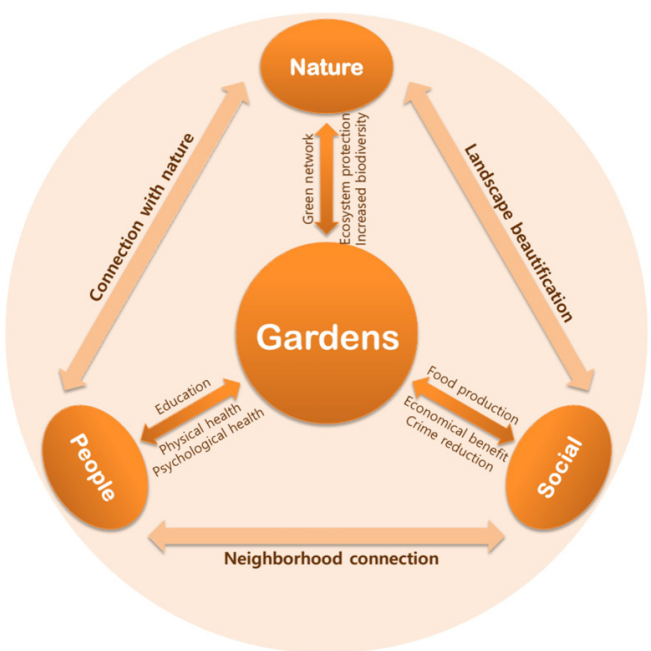

Fig. 3. Relationship among gardens, nature, people, and society. 


\section{References}

Algert, S.J., A. Baameur, and M.J. Renvall. 2014. Vegetable output and cost savings of community gardens in San Jose, California. J. Acad. Nutr. Diet. 114(7):1072-1076. https://doi.org/10.1016/j.jand.2014.02.030

Barthel, S. and C. Isendahl. 2013. Urban gardens, agriculture, and water management: sources of resilience for longterm food security in cities. Ecol. Econ. 86:215-225. https://doi.org/10.1016/j.ecolecon.2012.06.018

Belmeziti, A., F. Cherqui, and B. Kaufmann. 2018. Improving the multi-functionality of urban green spaces: Relations between components of green spaces and urban services. Sustain. Cities Soc. 43:1-10. https://doi.org/10.1016/j.sc s.2018.07.014

City of Sydney. 2016, February 29. Community gardens guidelines. Retrieved from https://www.cityofsydney.ns w.gov.au/policies/community-gardens-policy

Cho, T.B., S.R. Kim, and K.H. Kim. 2007. Research on the characteristics of garden design and dwellers' understanding of garden maintenance in single detached urban dwellings. J. Korean Inst. Landsc. Archit. 34(6):54-65.

Choi, H.J., J.A. Lee, H.J. Sohn, D.G. Cho, and Y.K. Song. 2017. Feasibility of green network in a highly-dense urbanized area by introducing urban gardens. Korean J. Environ. Ecol. 31(2):252-265. https://doi.org/10.1304 7/KJEE.2017.31.2.252

Choi, J.M., Y.N. Kim, and D.C. Park. 2018. A study on the desirable direction for Korean community gardens - Using case studies in Japan and questionnaire survey of Korean experts -. J. Resid. Environ. Inst. Korea 16(1): 83-104. https://doi.org/10.22313/reik.2018.16.1.83

Choi, S.R. and Y.S. Eom. 2018. Measuring economic values of amenity services from urban greenspaces in the Seoul metropolitan area using choice experiments. Environ. Resour. Econ. Rev. 27(1):105-138. https://doi.org/10.15266/KEREA.2018.27.1.105

Egli, V., M. Oliver, and E.S. Tautolo. 2016. The development of a model of community garden benefits to wellbeing. Prev. Med. Rep. 3:348-352. https://doi.org/10.1016/j.pm edr.2016.04.005

Ernwein, M. 2014. Framing urban gardening and agriculture: On space, scale and the public. Geoforum. 56:77-86. https://doi.org/10.1016/j.geoforum.2014.06.016
Fox-Kämper, R., A. Wesener, D. Münderlein, M. Sondermann, W. McWilliam, and N. Kirk. 2018. Urban community gardens: An evaluation of governance approaches and related enablers and barriers at different development stages. Landsc. Urban Plan. 170:59-68. https://doi.org/1 0.1016/j.landurbplan.2017.06.023

Fuller, R.A., K.N. Irvine, P. Devine-Wright, P.H. Warren, and K.J. Gaston. 2007. Psychological benefits of greenspace increase with biodiversity. Biol. Lett. 3(4):390-394. https://doi.org/10.1098/rsbl.2007.0149

Ginn, F. 2012. Dig for victory! new histories of wartime gardening in Britain. J. Hist. Geogr. 38(3):294-305. https://doi.org/10.1016/j.jhg.2012.02.001

Goddard, M.A., A.J. Dougill, and T.G. Benton. 2010. Scaling up from gardens: Biodiversity conservation in urban environment. Trends Ecol. Evol. 25(2):90-98. https://doi.org/10.1016/j.tree.2009.07.01

Guitart, D.A., C.M. Pickering, and J.A. Byrne. 2014. Color me healthy: Food diversity in school community gardens in two rapidly urbanising Australian cities. Health Place. 26:110-117. https://doi.org/10.1016/j.healthplace.2013.1 2.014

Han, B.H., J.I. Kwak, S.C. Park, and J.Y. Hur. 2014. A Study on planning of street tree and roadside green for enhancing urban green network. Korean J. Environ. Ecol. 28(2):128-141. https://doi.org/10.13047/KJEE.2014.28. 2.128

Hoff, J. 2016, April 4. How does your roof garden(business) grow? Roofing contractor. Retrieved from https://www.r oofingcontractor.com/articles/91524-how-does-your-roo f-garden-business-grow

Hwang, J.W. 2010. A study on the legal system of small garden from the viewpoint of urban regeneration. J. Korean Reg. Dev. Assoc. 22(4):169-184.

Jang, C.K., M.L. Hwang, J.Y. Shin, and S.G. Jung. 2017. Analysis of satisfaction on alley garden's components through urban regeneration: Focused on Bisan 2 - 3-dong in Daegu metropolitan city. J. Korean Inst. Landsc. Archit. 45(6):137-148. https://doi.org/10.9715/KILA.20 17.45.6.137

Jung, K.H. 2019a, August 26. Apartments with good 'community facilities' will show a greater increase in housing prices. Market Economy. Retrieved from http:// www.meconomynews.com/news/articleView.html?idxn 
$\mathrm{o}=32623$

Jung, K.H. 2019b, September 23. Landscaping and community determine apartment value: Construction companies are committed to specialized designs. Market Economy Mecon News. Retrieved from m.post.naver.com/viewer/ postView.nhn?volumeNo $=25609859 \&$ memberNo $=3579$ 7485

Kim, D.H., Y.S. Lee, and C.H. Ahn. 2010. A study on community shared space desired by apartment residents for super high rise apartment. J. Korean Hous. Assoc. 21(3):23-31. https://doi.org/10.6107/JKHA.2010.21.3.023

Kim, J.Y. and Y.S. Lee. 2013. A study on design direction of community garden in urban deprived area through analysis of psychological and social effects - Targeting on the community garden of Jeonju-si urban regeneration test-bed area - . Des. Converg. Study 12(6):83-98.

Kim, M.H. 2011. Study on the community garden model utilizing a small vacant space in urban area. Doctoral dissertation, Chonnam National University, Gwangju, Korea.

Kingsley, J.Y., M. Townsend, and C. Henderson-Wilson. 2009. Cultivating health and wellbeing: Members' perceptions of the health benefits of a Port Melbourne community garden. Leis. Stud. 28(2):207-219. https://doi. org/10.1080/02614360902769894

Korean Statistical Information Service. 2019. (General households) Housing Type by administrative district. Retrieved from http://kosis.kr/statHtml/statHtml.do?orgI $\mathrm{d}=116 \&$ tblId=DT_MLTM_5403\&conn_path=I2

Lee, A.R. and J.M. Park. 2018. Case study on the overseas locally-led community design guidelines. J. Korean Inst. Landsc. Archit. 46(3):117-129. https://doi.org/10.9715/ KILA.2018.46.3.117

Lee, H.B., Y.K. Yang, D.H. Lee, and H.S. Kim. 2017. Homes Koreans lived in: Korean contemporary dwelling life history (pp. 167-341). Seongnam, Korea: The Academy of Korean Studies Press.

Lee, J.H., J.Y. Kim, and J.K. Ahn. 2014. A study on the spatial composition of roof garden from concept of "Rhizome". J. Korea Inst. Spat. Des. 9(2):149-158.

Lee, S.H. 2011. The comparisons of urban, green roof, and forest scenes by rating psychological indices. Seoul Stud. 12(3):53-65.
Lee, Y.D. 2019, September 25. New apartment in resort city... popularity of line construction's 'Chuncheon Udu district EG the 1'. Daily Today. Retrieved from http://www. dtoday.co.kr/news/articleView.html?idxno=329676

Long, R. n.d. Small-scale Homesteading: How much do you really need? homestead.org. Retrieved December 27, 2020 from https://www.homestead.org/frugality-finance /small-scale-homesteading/

Martin, P., J.N. Consalès, P. Scheromm, P. Marchand, F. Ghestem, and N. Darmon. 2017. Community gardening in poor neighborhoods in France: A way to re-think food practices? Appetite 116:589-598. https://doi.org/10.1016 /j.appet.2017.05.023

Morris, R. 2013, December 10. Urban agriculture in Germany. Germany sustainable communities. Retrieved from https:// germanysustainablecommunities.wordpress.com/2013/1 2/10/urban-agriculture-in-germany/

National Law Information Center. 2019a. Enforcement ordinance on the creation and furtherance of arboretums and gardens (Presidential decree No. 29981). Retrieved from https://www.law.go.kr/LSW/lsInfoP.do?efYd=201 90716\&lsiSeq $=209939 \# 0000$

National Law Information Center. 2019b. Enforcement rule on development and support of urban agriculture (Ministry of Agriculture, Food and Rural Affairs decree No. 29981). Retrieved from https://www.law.go.kr/LSW/lsInfoP.do? efYd $=20190826 \& 1$ siSeq $=210411 \# 0000$

National Research Council, Institute of Medicine. 2013. Physical and social environmental factors. In: Woolf, S.H. \& L. Aron (Eds.), U.S. health in international perspective: shorter lives, poorer health. Washington, USA: National Academies Press. Retrieved from https://www. ncbi.nlm.nih.gov/books/NBK154491/

Nordh, H. and K. Østby. 2013. Pocket parks for people - A study of park design and use. Urban For. Urban Green. 12(1):12-17. https://doi.org/10.1016/j.ufug.2012. 11.003

Park, E.J., Y.S. Lee, and C.H. Ahn. 2011. Characteristics of community garden based on social capital perspectives. J. Korea Inst. Ecol. Archit. Environ. 11(6):117-125.

Park, E.Y. and H.S. Lee. 2014. Analysis of preferences and a sense of healing among the healing gardens at the 2014 Korean garden show. J. Korean Soc. People Plants Environ. 17(5): 379-385. https://doi.org/10.11628 
/ksppe.2014.17.5.379

Park, G.W. 2019, October 24. The view of apartment is 'hot'..'The era of 'view'. Youth Daily. Retrieved from http://www.youthdaily.co.kr/news/article.html?no=20840

Park, K.Y. 2012. The impact of vertical garden formation on plant growth and the environment. PhD-thesis, Kyung Hee University, Seoul, Korea.

Riley, D. 2017, February 14. School garden notes so far in 2017. Brisbane local food. Retrieved from http:/brisb anelocalfood.ning.com/profiles/blogs/school-garden-not es-so-far-in-2017

Rural Development Administration. 2020. Community Garden Design Guidelines (for social integration). Retrieved from https://dl.nanet.go.kr/SearchDetailView.do?cn=MONO1 202030956

Samantha. 2019, January 9. What's the difference between a kitchen garden and a regular vegetable garden? Just Dabbling Along. Retrieved from https://www.justdabbli ngalong.com/difference-between-kitchen-garden-regular -vegetable-garden/

Sampaio, M.B., M.F. De La Fuente, U.P. de Albuquerque, A. da Silva Souto, and N. Schiel. 2018. Contact with urban forests greatly enhances children's knowledge of faunal diversity. Urban For. Urban Green. 30:56-61. https://doi.org/10.1016/j.ufug.2018.01.006

Savard, J.P.L., P. Clergeau, and G. Mennechez. 2000. Biodiversity concepts and urban ecosystems. Landsc. Urban Plan. 48(3-4):131-142. https://doi.org/10.1016/S0 169-2046(00)00037-2

Shin, M.J. and J.M. Choi. 2018. Case study of the roles and characteristics of community gardens in four North American cities. J. Korean Inst. Landsc. Archit. 46(6): 26-40. https://doi.org/10.9715/KILA.2018.46.6.026

Sierra-Guerrero, M.C. and A. R. Amarillo-Suárez. 2017. Socioecological features of plant diversity in domestic gardens in the city of Bogotá, Colombia. Urban For. Urban Green. 7:28, 54-62. https://doi.org/10.1016/j.ufu g.2017.09.015

Sim, J.Y. and K.J. Zoh. 2015. Examination of urban gardening as an everydayness in urban residential area, Haebangchon. J. Korean Inst. Landsc. Archit. 43(2):1-12. https://doi.org/10.9715/KILA.2015.43.2.001

Speak, A.F., A. Mizgajski, and J. Borysiak. 2015. Allotment gardens and parks: Provision of ecosystem services with an emphasis on biodiversity. Urban For. Urban Green. 14(4):772-781. https://doi.org/10.1016/j.ufug.2015.07.007

Sung, C.W. and J.K. Lee. 2013. A study of implications on art community garden for the activation of the community -Case study of oversea art community garden-. J. Korea Inst. Spat. Des. 8(1):33-42. https://doi.org/10.3 5216/kisd.2013.8.1.33

Teig, E., J. Amulya, L. Bardwell, M. Buchenau, J.A. Marshall, and J.S. Litt. 2009. Collective efficacy in Denver, Colorado: Strengthening neighborhoods and health through community gardens. Health Place 15(4): 1115-1122. https://doi.org/10.1016/j.healthplace.2009.06.003

United Nations Human Settlement Programmes, Global Urban Observatory. 2018, July 9. Green area per capita (square meters per capita). Retrieved from https://data.h umdata.org/dataset/green-area-per-capita-square-metersper-capita

Van den Berg, A.E., M. van Winsum-Westra, S. de Vries, and S.M.E. van Dillen. 2010. Allotment gardening and health: A comparative survey among allotment gardeners and their neighbors without an allotment. Environ. Health. 9(1):74. https://doi.org/10.1186/1476-069X-9-74

Wang, H., F. Qiu, and B. Swallow. 2014. Can community gardens and farmers' markets relieve food desert problems? A study of Edmonton, Canada. Appl. Geogr. 55:127-137. https://doi.org/10.1016/j.apgeog.2014.09.010

Woo, K.S. and J.H. Suh. 2016. A study on the contemporary definition of 'GARDEN' - Keyword analysis used literature research and big data. J. Korean Inst. Landsc. Archit. 44(5):1-11. https://doi.org/10.9715/KILA.2016.44.5.001

World Urbanization Prospects. 2018. Population of urban and rural areas at mid-year (thousands) and percentage urban. United Nations: Author. Retrieved from https://p opulation.un.org/wup/Download/

Yard and garden extension. 2018. How and why to build a rain garden. University of Minnesota extension. Retrieved from https://extension.umn.edu/landscape-design/rain-g ardens

Zick, C.D., K.R. Smith, L. Kowaleski-Jones, C. Uno, and B.J. Merrill. 2013. Harvesting more than vegetables: The potential weight control benefits of community gardening.Am. J. Public Health 103(6):1110-1115. https://doi.org/10.2105/AJPH.2012.301009 